\title{
Suppression of Soilborne Plant Pathogens through Community Evolution of Soil Microorganisms
}

\author{
RYO FUKUI ${ }^{1 *}$ \\ ${ }^{1}$ Department of Bio-productive Science, Faculty of Agriculture, Utsunomiya University, 350 Mine, \\ Utsunomiya, Tochigi 321-8505, Japan
}

(Received December 13, 2002-Accepted January 17, 2003)

\begin{abstract}
A distinct microbial community is established in a given environment as a consequence of the community evolution of individual component microorganisms. According to the "Community Theory", microorganisms proliferate not as individual species but as a community in response to changes in the environment, evolving into a biological network that is most suitable for their survival and/or further growth. During this process, individual microorganisms interact and communicate with each other by sharing their limited genetic information in order to exploit available resources. Consequently, a functional community comprising many different species is formed. Such microbial communities are comparable to multi-cellular organisms in many ways, but often too complex to be characterized. Nutrient enrichment is one approach to the study of the functions of these inextricably linked biological networks. For soil microbial communities, amendment with organic matter can be employed to apply selective environmental advantages in order to transfer microbial communities to newly evolved biological consortia with distinctive functions. Many studies have reported that the incorporation of composts or green manures rendered soils suppressive to various soilborne pathogens. Among the pathogens that are controlled effectively are Pythium, Phytophthora, and Rhizoctonia. Soil enrichment with organic matter may be the most fundamental and sustainable approach to the biological control of soilborne diseases.
\end{abstract}

Key words: community evolution, natural antagonism, disease suppression, biological control, sustainable agriculture

\section{Community Theory}

The term "microbial community" or "bacterial community" is frequently used to describe a biological unit consisting of different microorganisms and its complexity. The term relates to the "Community Theory" originally proposed by Caldwell et al. ${ }^{11)}$, which was based on the supposition that changes or constraints in the environment influence entire microbial populations instead of affecting each individual species independently. In this case, microorganisms proliferate in response to the environment,

\footnotetext{
* Corresponding author; E-mail: ryo@cc.utsunomiya-u.ac.jp, Tel: +81-28-649-5420, Fax: +81-28-649-5401
}

evolving into a biological network that is most suitable for survival and/or further growth ("Proliferation Hypothesis"). It is assumed that individual species in a microbial community interact and communicate with each other to support and sustain themselves, and the loss of any component species or the stable community structure could risk the function of the entire community. Examples of such stable, inter-dependent microbial communities include anaerobic digestor granules, degradative consortia, spoilage and corrosion biofilms, and kefir ${ }^{11)}$.

There are several key ecological connections to this concept. The limited genetic resources in bacteria may be the most significant reason that communication or interaction between species is more likely to occur in bacteria than 
plants or animals ${ }^{11)}$. The total amount of DNA in bacteria is limited as compared to more advanced multi-cellular $\operatorname{organisms}^{8}$. Nonetheless, "bacteria" thrive in every corner of the earth under diverse environmental conditions and perform a variety of biological and biochemical functions; some of which cannot be achieved by plants and animals, or even by human technology. Bacteria may be inter-dependent on the genetic information of others in the community to exploit available resources under a given environment. Consequently, bacterial communities that share genetic resources among their members have an advantage over communities that do not. For instance, studies have shown that degradative plasmids move among beta and gamma subgroups of the Proteobacteria when a strong environmental constraint, 3-chlorobenzoate as a carbon source, is applied $^{27,28)}$. Similarly, it is well known among plant pathologists that plasmids encoding antibiotic resistance move rapidly among strains of pathogenic bacterial species or genetically unrelated species when antibiotics are applied for disease control ${ }^{62)}$. Plasmid is not the only means of sharing genetic information. Studies of biodegradation showed that bacterial communities responded to chlorinated hydrocarbons by forming degradative consortia consisting of populations that are unable to degrade the hydrocarbons as isolated populations ${ }^{1,21,39)}$. These examples indicate that collaborative uses of genetic information within microbial communities are common phenomena, and some microbial populations can achieve distinctive functions by forming specialized consortia.

\section{Examples of well-studied functional microbial consortia}

Technologies such as confocal laser scanning microscopy have enabled the in situ examination of microbial communities in three-dimensional sections without needs to dry specimens for microscopic observation ${ }^{69}$. Clear pictures of slices at different depths within a bacterial colony led to a new era of microbial ecology. The concept of a microbial community emerged about a quarter century ago. In 1977, Geesey et al. re-examined bacteria in natural aquatic systems and found that bacterial cells predominantly attached to surfaces and were rarely swimming freely in the water ${ }^{30)}$. It was later demonstrated that such attachments are ubiquitous in nature ${ }^{16}$. These findings have led to the recognition of multi-cellular behavior in bacteria and interactions (communications) between the cells in a colony ${ }^{59}$.

Numerous reports have illustrated the processes of community development in bacterial populations during their proliferation, and some bacterial consortia were shown to possess new functions that are not achieved by individual bacterial populations. Such specialized functions of bacterial consortia (microbial communities) include anaerobic fermentation $^{41,65)}$, the degradation of petrolic compounds and other hydrocarbons (bioremidiation) ${ }^{4}$, the formation of dental plaque ${ }^{7,63)}$, and antibiotic resistance ${ }^{18)}$.

One microbial community that has been well studied and described is "biofilm", consisting of multiple bacterial species that colonize hydrated surfaces of metals, plastics, and teeth. The structural and biological features of biofilms have been reviewed previously ${ }^{17,52}$. Briefly, species of early colonizers initially start to colonize a surface, forming microcolonies $^{40,44)}$. When sufficient nutrients are available, colonies will proliferate and produce extracellular polysaccharides ${ }^{35)}$ or newly synthesized proteins ${ }^{51)}$ as they enlarge. Soon the colonies are well protected from the surrounding environment by a "film structure", and start to express specific genes when the population within the colonies reaches certain levels ${ }^{20}$. By this time, different bacterial species may join the developing biofilm to form a further complex of bacterial populations. As a consequence, the biofim promotes the coexistence of diverse species and acquires new capabilities that are not performed by individual species: for instance, antibiotic resistance, biodegradation of polymers, and metal corrosion ${ }^{18}$. Biofilms composed of a single bacterial species include those of Pseudomonas aeruginosa, P. fluorescens, Escherichia coli, Vibrio cholerae, Staphylococcus aureus, and S. epidermis, while dental plaque is one example of a biofilm comprised of multiple species $^{7,52,63)}$. Biofilms have also been implicated in periodontal disease, prostate infection, kidney stones, tuberculosis, Legionnaire's disease and some infections of the middle ear ${ }^{18}$.

Antibiotic resistance is one of the acquired functions of certain biofilms, and is believed to be responsible in part for the failure of antibiotic treatment in hospitals. In such cases, antibiotic resistance is not due to the emergence of resistant strains by mutation or the acquisition of plasmids, but appears to be induced by different mechanisms. The strains isolated from the patients were sensitive to the antibiotics in culture media, but the antibiotics were not effective when used for treatment. For instance, $P$. aeruginosa is known to produce a large amount of alginate, a different kind of extracellular polysaccharide that is not produced by individual cells, during the formation of its biofilm. Since alginate is impermeable to tobramycin, bacterial cells inside the biofilm are not inhibited by this antibiotic ${ }^{35,49}$. Similarly, penicillin cannot penetrate biofilms if they contain cells 
producing $\beta$-lactamases ${ }^{18)}$. Even if cells in the biofilm do not synthesize $\beta$-lactamases, they may still be protected. Since penicillin attacks only replicating cells of gram positive bacteria, the antibiotic should kill actively dividing cells near the surface of the colony but may not affect cells deep inside the colony that could be starved and hence not multiply. Once the effect of the antibiotic disappears, a few surviving cells then can use nutrients from the dead cells to grow and restore the biofilm to its original state in a matter of hours. This could explain why antimicrobial agents work against cultured cells but often fail in battling real disease situations. It is also known that biofilms are not readily removed even by bleach ${ }^{18)}$. These examples suggest that some functions of bacterial communities are comparable to those seen in multi-cellular organisms.

\section{Biofilms found in association with plants}

Although the term biofilm has been applied recently to the phylloplane microbial communities on some plants ${ }^{45,46)}$, there have been limited clear descriptions of the state of biofilms or their analogs developing on roots or in association with plants. Ruinen ${ }^{58)}$, who was probably the first to describe a multi-layered, multi-species biofilm on the phylloplane, observed a living layer of microbes estimated at $22 \mu \mathrm{m}$ or more in thickness on the leaves of various plants growing in the humid tropics. This suggests that plant biofilms that are structurally and functionally comparable to the biofilms developing in aquatic or medical environments likely occur on long-lived leaves where free water is frequently present under warm and moist conditions. However, in most of the phylloplanes investigated thus far, the extent of leaf coverage by epiphytic microbes was typically $<10 \%$ or often $<1 \%$ among plants growing in relatively cool, dry, temperate regions ${ }^{3)}$. Microbial colonization patterns are related to topographic features of leaves such as veins, trichomes, stomata, epidermal cell junctions, depression in the cuticle, and hydathodes ${ }^{2}$. Similarly, microbial colonization on the root mostly coincides with features such as the junctions of anticlinal cell walls or sloughed epidermal cells near the root tip. Yet, colonization of roots, primarily by bacteria, varies from $<1 \%$ to at most about $15 \%$ of the tip region ${ }^{32,57)}$. In this way, microbial colonization patterns in association with plants are confined to those sites that provide microbes with physical protection or nutrients (i.e. exudates), and hence should be described as "aggregates" rather than a continuum of microbial films ${ }^{3)}$. In fact, epiphytic and rhizosphere bacterial populations are known to be log-normally distributed ${ }^{33,42)}$.
However, these aggregated colonization patterns have some ecological implications. First, a quorum sensing system regulated by diffusible signal molecules has been found in some soilborne plant pathogens and other soil-inhabiting bacteria (see below). Second, the horizontal transfer of genes (e.g. virulence, antibiotic resistance, etc.) has been demonstrated in roots ${ }^{38)}$ and leaves ${ }^{50)}$ of plants growing in controlled and field conditions. Finally, aggregation itself may promote the survival of bacteria by protecting the individual cells from various chemical and physical stresses. It is known that the inhibitory effects of antibiotics are often lost when they are directly applied to the soil to control soilborne pathogens. It has been proposed that the antibiotics are either inactivated through absorption by clay particles and soil organic matter or degraded by soil microorganisms ${ }^{9)}$. Yet, no conclusive evidence has been provided to explain this phenomenon. The mechanism of antibiotic resistance demonstrated in medical biofims may provide clues to explain the failure of antibiotic treatment in soil.

\section{Quorum sensing: the means by which bacteria communicate}

Evidence is accumulating of the existence of signal molecules by which bacterial cells communicate with each other and induce specific functions within a community as the population increases and reaches a critical level ${ }^{60)}$. Such population-dependent communication is known as "quorum sensing", in which low molecular weight compounds constitutively produced by the cells at low levels induce the expression of specific genes in the cells of the same bacteria or of different species when their concentrations reach certain critical levels ${ }^{31,36}$. The signal molecules are $\mathrm{N}$ acyl-homoserine lactones or related compounds, and are responsible for controlling the function of a bacterial community and regulating its multi-cellular behavior ${ }^{29,55)}$.

The system of quorum sensing was first found to operate in the expression of genes responsible for bioluminescence in Photobacterium fischeri ${ }^{22}$. A similar system also operates in the aforementioned biofilms ${ }^{17,52)}$ and in populations of various bacterial species ${ }^{60)}$ including some edaphic bacteria and several soilborne plant pathogens. Studies have shown that accumulations of the signal molecules regulate the conjugational transfer of Ti plasmid in Agrobacterium tumefaciens $^{23)}$, production of macerating coenzyme by Erwinia carotovora ${ }^{54)}$ and pathogenicity-related extracellular polysaccharides by Pantoea stewartii ${ }^{68)}$, induction of competent cells in Bacillus subtilis ${ }^{43,64)}$, and production of the antibiotic phenezine by Pseudomonas aureofaciens ${ }^{53)}$. 
It is important to note that the signal molecules produced by certain strains of Pseudomonas, Erwinia, Rhizobium, and Bradyrhizobium also induce the conjugational transfer of $\mathrm{Ti}$ plasmid in A tumefaciens $^{23}$. In the event of quorum sensing in $P$. aureofaciens, production of phenezine leads to inhibition of Gaeumonnnomyces graminis var. tritici, the fungal pathogen causing take-all in barley and wheat ${ }^{53)}$. The proliferation of $P$. aureofaciens in soil during an extended monoculture of wheat resulted in the natural suppression of take-all in the field, the phenomenon known as "take-all decline"14). This suggests that the behavior of one species may be regulated by different bacterial species in the soil microbial community and, proliferation of one species could influence other members of the community during community evolution.

In plant pathology, in general, plant pathogens have been studied in terms of "one-on-one" relationships: i.e., the pathogen and its host, the pathogen and the disease, or the pathogen and its antagonist. However, it is likely that some types of disease or disease suppression are caused by multiple species of microorganisms or their interactions. For instance, poor root growth of strawberry in monoculture fields in California was alleviated only by soil fumigation. In this case, no single pathogen was responsible for the root damage, and strawberry production in California still depends heavily on soil fumigation ${ }^{13}$. In such situations, the causal agent appears to be a specific community of individual soil microorganisms. Similarly, a certain bacterial disease was suppressed by a specific bacterial community but not by the individual bacterial species (see below). These examples suggest that some phenomena concerning plant diseases cannot be elucidated by the methods and approaches based on "one-on-one" relationships. Therefore, disease suppression and the behavior of plant pathogens need to be studied in relation to the community theory where appropriate.

\section{Growth and death in bacterial communities}

While some populations of bacteria proliferate and exhibit new functions during the development of microbial communities, others are reduced in size as well as in their roles. In other words, a continuum of growth and death occurs in each microbial community, and the community will eventually reach a state of equilibrium. Such growth and death could also occur under conditions where the supply of nutrients is insufficient or very limited. However, death itself does not result in the extermination of declining species within a community during the process of species succession toward a state of equilibrium. It has been shown in chemostat studies in which two bacteria are grown together in culture, one exhibiting a copiotrophic growth pattern and the other an oligotrophic growth pattern, that the former proliferates at high substrate concentrations and vice versa. However, neither dies as a consequence of the other ${ }^{66,67)}$. There appears to be a gradual displacement of one strategy by another as the bacterial community evolves, and neither death nor the direct inhibition of one organism by the other controls this phenomenon ${ }^{11)}$.

The same principle was seen in a slightly more complex bacterial community comprising indigenous bacterial strains isolated from guttation fluids of anthuriums (Fig. 1) and Xanthomonas axonopodis pv. dieffenbachiae, the pathogen causing bacterial blight in anthuriums and other aroids. When the pathogen was inoculated to non-sterilized guttation fluids collected from various cultivars, the population of the pathogen declined over time regardless of the susceptibility of the cultivars. However, the pathogen population did not decline when introduced into filter-sterilized individual guttation fluids. Then, numbers of bacterial strains were isolated from guttation fluids of various cultivars and the pathogen was co-inoculated with each individual strain or with several strains mixed in various combinations. The results showed that the pathogen population declined drastically when co-inoculated with certain specific combinations of strains but not when co-inoculated with any individual strains (Fig. 2) ${ }^{24}$. One of the most inhibitory combinations consisted of strains of Sphingomonas chlorophenolica, Microbacterium testaceum, Brevundimonas

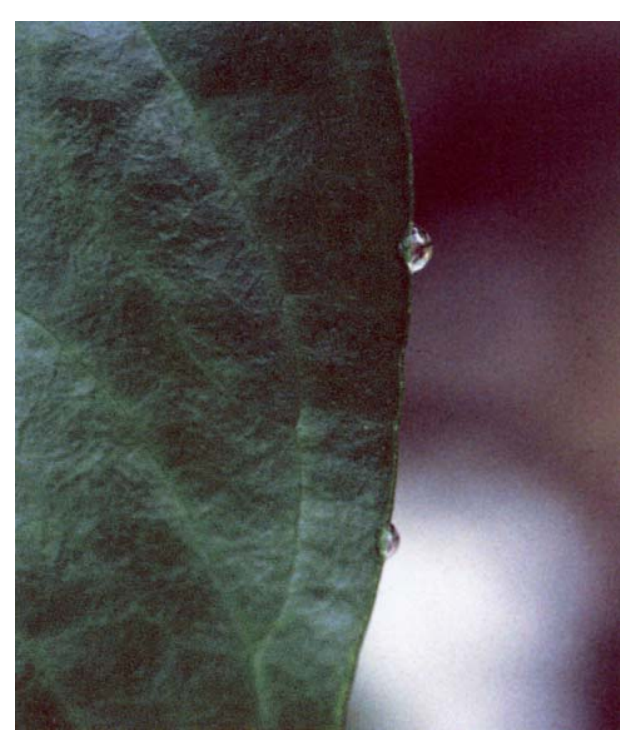

Fig. 1. Guttation fluid released from the margins of an anthurium leaf. 


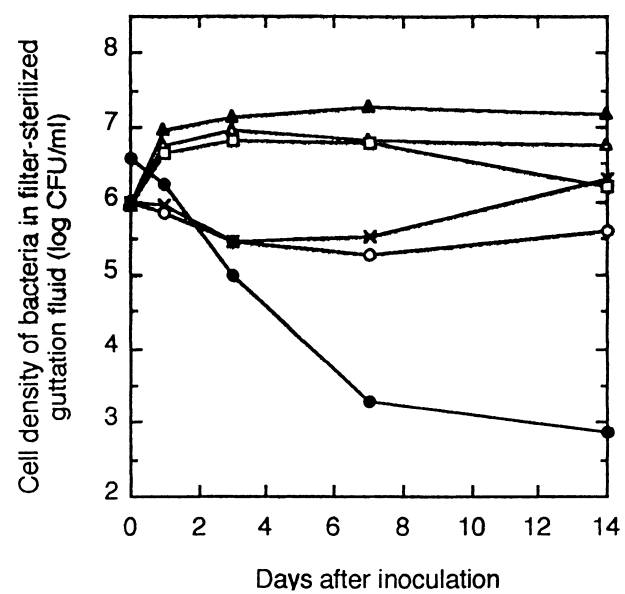

Fig. 2. Survival of $X$. axonopodis pv. dieffenbachiae (strain V108LRUH1) co-inoculated with an inhibitory bacterial mixture in filter-sterilized guttation fluids of anthuriums ${ }^{24}$. Symbols: - V108LRUH1; $\bigcirc$, Sphingomonas chlorophenolica; $\triangle$, Microbacterium testaceum; $\times$, Brevundimonas vescularis; $\square$, Herbaspirillum rubrisubalbicans; and $\mathbf{\Lambda}$, Alcaligenes sp.

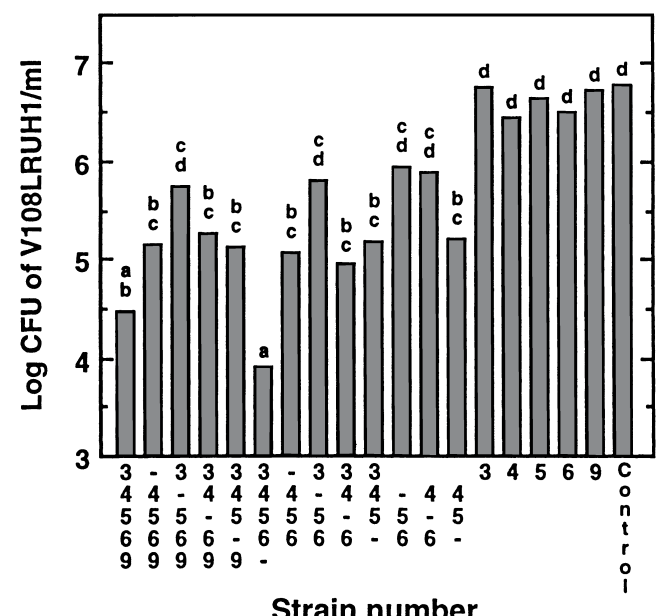

Fig. 3. Inhibitory effects of various bacterial communities on survival of $X$. axonopodis pv. dieffenbachiae (strain V108LRUH1) after 14 days of incubation in filter-sterilized guttation fluids of anthuriums ${ }^{25}$. The initial cell density of V108LRUH1 was approximately $6.60 \mathrm{log} \mathrm{cfu} / \mathrm{ml}$. The values with the same letters are not significantly different $(P=0.01)$ according to StudentNewman-Keuls tests.

vescularis, Herbaspirillum rubrisubalbicans, and Alcaligenes sp. ${ }^{25,26)}$, but some other combinations were also as inhibitory as this one. It was also observed that the inhibitory effect was reduced as one strain each was removed systematically from the mixture, and some of the mixtures consisting of two strains was not inhibitory to the pathogen (Fig. $3)^{25)}$. These results indicate that certain kinds of bacterial mixtures (bacterial community) formed on or inside plants exhibit exceptional effects that are normally not produced by individual bacteria. In this case, the effect produced by a specific bacterial community was suppression of the blight pathogen. In fact, greenhouse tests proved that the disease could be suppressed when the plants were sprayed with the 5-strain mixture and then challenge-inoculated with the pathogen ${ }^{24,25)}$. However, it is important to note that, as described in the aforementioned chemostat studies, the pathogen could not be exterminated within the suppressive bacterial community that formed in the guttation fluids as well as in association with the plant.

This example of disease suppression suggests that the state of a microbial community at a given time or during its establishment has a significant impact on the growth and survival of unfavorable microorganisms. Thus, it is possible to contain or displace plant pathogens through community evolution within the microbial populations even in a more complex environment such as soil. It is well known in plant pathology that this kind of disease containment operates in soil: namely "suppressive soil". The concept has been interpreted in terms of "community evolution" only recently, but the phenomenon truly represents the state of an evolved edaphic microbial community that is unfavorable to the survival or activity of the pathogen. For instance, it has been known for many years that there are two types of soil in terms of survival of Ralstonia solanacearum, the bacterial pathogen responsible for southern bacterial wilt in many solanaceous plants: one in which bacterial wilt is a consistent problem (persistent soil) and another in which the disease does not persist (non-persistent soil). The pathogen declines more rapidly in the non-persistent than persistent soil ${ }^{9)}$. It was shown that the disease developed in susceptible tomato cultivars planted in persistent soil and in both types of soil when the soils were fumigated ${ }^{47,48)}$. However, the disease did not develop in non-fumigated non-persistent soil. Some intrinsic soil factors, probably of microbial origin, affected the survival of the pathogen in this case.

Soil suppressiveness may be established or lost over a long timeframe ${ }^{15)}$, or even transferred to conducive soils ${ }^{61)}$. Many examples of suppressive soil have been described ${ }^{9,14)}$. It is doubtless that such suppressive microbial communities are regulated and maintained by a most inextricable web of "signals" and "interactions" among soil microorganisms, although the exact mechanisms of soil suppressiveness have not been elucidated in all cases. However, it is not a simple task to sort out and characterize the individual microorganisms in soil to make a complete list. It is even more difficult or nearly impossible to analyze a soil microbial community 
by characterizing it using a model community that is systematically constructed with individual microorganisms or groups of microorganisms in the laboratory.

\section{Soil enrichment: sustainable approach to biological control of soilborne diseases}

Soil enrichment with a specific nutrient is one approach to the study of community evolution in soil microorganisms and its impact on unfavorable microorganisms. In response to a specific nutrient, a soil microbial community starts to proliferate and evolve into a specialized biological network that is most suitable for its survival and further growth. Some species may be retained or displaced during this process.

In agriculture, a practical and effective method of soil enrichment is soil amendment with organic matter. Many studies have indicated that soil amendment with green manure, stable manure, or compost is effective in mitigating disease problems caused by various soilborne fungal pathogens including Pythium spp., Phytophthora spp., and Rhizoctonia solani ${ }^{34)}$. These pathogens are known to cause seedling diseases and infections of fibrous roots in various herbaceous as well as woody plant species. For instance, incorporating green manure into sand before the establishment of the lawn controlled damping-off and root rot of creeping bentgrass by Pythium graminicola on a golf course ${ }^{19}$. Soil amendment with cotton-gin trash or swine manure was highly effective in mitigating southern blight of tomato caused by the fungal pathogen Sclerotium rolfsii. In this case, the populations of Trichoderma and Pseudomonas were increased in soil in response to organic amendment ${ }^{10)}$. The mechanism of disease mitigation by organic amendment is due primarily to amplified competition for available nutrients and suitable ecological niches through enhancement of edaphic microorganisms, or parasitism and/or antibiosis by antagonists (potential biocontrol agents) that also proliferate with organic amendment ${ }^{27}$. In some cases, all of these mechanisms are likely to operate in combination. This approach to disease control is important in sustainable agriculture, since it reuses natural resources in the process of disease control without using chemicals. In addition, it does not require the mass culturing of biocontrol agents for applications to large fields.

However, the current approach also has some drawbacks and/or limitations; the effect on disease mitigation is affected by the composition of organic matter or the changes of microflora in a compost during the decomposition process. Inhibitory effects produced by residues of cruciferous plants incorporated into soil on the growth and survival of $R$. solanacearum differ greatly depending on the plant species (R. Fukui, unpublished). Composts made of tree barks containing large amounts of cellulosic substances are primarily colonized by Trichoderma and other cellulose-degrading fungal species, while Penicillium, Aspergillus and copiotrophic bacteria (such as Pseudomonas, Bacillus, and Pantoea [formerly Erwinia]) preferably colonize composts made of grape pomace that contains large amounts of sugars $^{34)}$. As the composts are further decomposed, oligotrophic bacteria colonize then. In general, Pythium and Phytophthora are controlled relatively readily by the incorporation of composts colonized by copiotrophs into soil but not with those colonized by oligotrophs ${ }^{5,6}$. In contrast, amendment of the compost itself is not very effective in controlling infection by Rhizoctonia; the introduction of certain species of Trichoderma ${ }^{34)}$ or addition of cellulose to the compost is needed ${ }^{56}$. It appears that Rhizoctonia can be inhibited by a much narrower spectrum of antagonists and hence a specific combination of microbes consisting of certain bacteria and Trichoderma seems to be required for effective control ${ }^{37}$.

There is no doubt that more examples of effective disease control by soil amendment will follow. It is essential to accumulate more findings and knowledge on the community evolution of soil microorganisms in order to establish consistent and reliable methods of disease control that can be applied in a wide range of conditions and situations over a long period of time. One of the key aspects to be studied is the selectivity or specificity of each organic substrate incorporated into soil on species succession during community evolution. Species succession may also differ depending on the environmental condition, soil type, and cropping history of the field. It is worth noting that a simple organic substrate can alter the function of a microbial community significantly. For instance, the suppression of $X$. axonopodis pv. dieffenbachiae by an inhibitory bacterial community was further enhanced when $\alpha$-cyclodextrin was added to the guttation fluid (R. Fukui, unpublished), but was nullified when a complex of nutrients such as peptone or yeast extract was supplemented ${ }^{24)}$. These results suggest that the functions of microbial community may be modified purposely by additions of certain nutrients, and biocides or biostatics are not the only chemicals to be used to control these functions. Soil enrichment with simple organics (sugars and amino acids) may be a useful experimental approach to studying of the community evolution of soil microorganisms and the mechanism of suppression of soilborne plant diseases. 
Another important aspect in terms of research is the process of fermentation itself. As described above, organic substrates have significant roles in determining species succession during the process of composting. In Japan, increasing amounts of city food wastes and excretions from animal husbandry are becoming a major public concern. It is, therefore, essential to establish a method of controlling the fermentation process to produce a quality compost from organic wastes not only to provide nutrients to crops but also to improve plant health through the mitigation of soilborne diseases. Thus far, there has been no established linkage between industrial fermentation and plant health management.

Despite the limitations and shortcomings of the current approach, the use of organic matter is expected to play a very important role in sustainable agriculture in the 21 st century. The approach not only could be used to control many, if not all, soilborne diseases but also provides nutrients to crops and organic matter to the soil, and enhances the circulation of organic carbon in the environment. It also reduces soil erosion by facilitating flocculation through enhanced activities of basidiomycetous fungal species in soil $^{12}$. All these advantages of organics have been overshadowed by the effects of chemicals, and overlooked or even forgotten during the modernization of agriculture in the previous century. Consequently, a heavy dependence on chemical fertilizers and pesticides produced a variety of environmental pollutants. Understanding the role of organics in the community evolution of soil microorganisms may allow growers and researchers to re-establish the link between organic amendments, soil fertility and agricultural productivity.

\section{References}

1) Aftrinf, R.P., B.E. Chalker and B.F. Taylor. 1981. Degradation of phthalic acids by denitrifying mixed cultures of bacteria. Appl. Environ. Microbiol. 41: 1177-1183.

2) Andrews, J.H. 1992. Biological control in the phyllosphere. Annu. Rev. Phytopathol. 30: 603-635.

3) Andrews, J.H. and R.F. Harris. 2000. The ecology and biogeography of microorganisms on plant surfaces. Annu. Rev. Phytopathol. 38: 145-180.

4) Atlas, R.M. and R. Bartha. 1992. Hydrocarbon biodegradation and oil spill bioremediation, p. 287-338. In K.C. Marshall (ed.), Advances in Microbial Ecology, Volume 12. Plenum Press, New York, NY.

5) Boehm, M.J., L.V. Madden and H.A.J. Hoitink. 1993. Effect of organic matter decomposition level on bacterial species diversity and composition in relationship to Pythium damping-off severity. Appl. Environ. Microbiol. 59: 4171-4179.

6) Boehm, M.J., T. Wu, A.G. Stone, B. Kraakman, D.A. Iannotti, G.E. Wilson, L.V. Madden and H.A.J. Hoitink. 1997. Cross-po- larized magnetic-angle spinning $13 \mathrm{C}$ nuclear magnetic resonance spectroscopic characterization of soil organic matter relative to culturable bacterial composition and sustained biological control of Pythium root rot. Appl. Environ. Microbiol. 63: 162-168.

7) Bradshaw, D.J., A.S. McKee and P.D. Marsh. 1989. Effects of carbohydrate pulses and $\mathrm{pH}$ on population shifts within oral microbial communities in vitro. J. Dent. Res. 68: 1298-1302.

8) Brock, T.D. and M. Madigan. 1988. The biology of microorganisms. Prentice-Hall, New Jersey.

9) Bruehl, G.W. 1987. Soilborne plant pathogens. Macmillan Publishing Company, New York, NY.

10) Bulluck, L.R. and J.B. Ristaino. 2002. Effect of synthetic and organic soil fertility amendments on southern blight, soil microbial communities, and yield of processing tomatoes. Phytopathology 92: $181-189$

11) Caldwell, D.E., G.M. Wolfaardt, D.R. Korber and J.R. Lawrence. 1997. Do bacterial communities transcend Darwinism?, p. 105191. In J.G. Jones (ed.), Advances in Microbial Ecology, Volume 15. Plenum Press, New York, NY.

12) Caesar-TonThat, T.C. and V. Cochran. 2000. Soil aggregate stabilization by a saprophytic lignin decomposing basidiomycete fungus: I. Microbiological aspects. Biology and Fertility of Soils 32: 374-380.

13) Carpenter, J., L. Lynch and T. Trout. 2001. Township limits on 1.3-D will impact adjustment to methyl bromide phase-out. California Agriculture 55: 12-18.

14) Cook, R.J. and K.F. Baker. 1983. The nature and practice of biological control of plant pathogens. The American Phytopathological Society, St. Paul, MN.

15) Cook, R.J. and A.D. Rovira. 1976. The role of bacteria in the biological control of Gaeumannomyces graminis by suppressive soils. Soil Biol. Biochem. 8: 267-273.

16) Costerton, J.W., G.G. Geesey and K-J. Cheng. 1978. How bacteria stick. Sci. Am. 238: 86-95.

17) Costerton, J.W., Z. Lewandowski, D.E. Caldwell, D.K. Korber and H.M. Lappin-Scott. 1995. Microbial biofilms. Annu. Rev. Microbiol. 49: 711-745.

18) Costerton, J.W. and P.S. Stewart. 2001. Battling biofilms. Sci. Am. 285: 60-67.

19) Craft, C.M. and E.B. Nelson. 1996. Microbial properties of composts that suppress damping-off and root-rot of creeping bentgrass caused by Pythium graminicola. Appl. Environ. Microbiol. 62: 1550-1557.

20) Davies, D.G., M.R. Parsek, J.P. Pearson, B.H. Iglewski, J.W. Costerton and E.P. Greenberg. 1998. The involvement of cell-tocell signals in the development of a bacterial biofilm. Science 280: 295-298.

21) Dawson, K.A., M.J. Allison and P.A. Hartman. 1980. Characteristics of anaerobic oxalate degrading enrichment cultures from the rumen. Appl. Environ. Microbiol. 40: 840-846.

22) Eberhard, A. 1972. Inhibition and activation of bacterial luciferase synthesis. J. Bacteriol. 109: 1101-1105.

23) Ferrand, S.K., K.R. Piper, R. Sackett, G. Ping, P.D. Shaw and K.-S. Kim. 1996. Homoserine lactone-mediated microbial signaling: A communication system common to plant-associated bacteria, p. 173-179. In J. Stacey, B. Mullin, and P.M. Gresshoff (ed.), Biology of Plant-Microbe Interactions. International Society for Molecular Plant-Microbe Interactions, St. Paul, MN.

24) Fukui, R., H. Fukui and A.M. Alvarez. 1999. Suppression of bacterial blight by a bacterial community isolated from the guttation 
fluids of anthuriums. Appl. Environ. Microbiol. 65: 1020-1028.

25) Fukui, R., H. Fukui and A.M. Alvarez. 1999. Comparisons of single versus multiple bacterial species on biological control of anthurium blight. Phytopathology 89: 366-373.

26) Fujii, T.M., A.M. Alvarez, R. Fukui, K. Obsuwan and A.R. Kuehnle. 2002. Effect of transgenic anthuriums producing the Shiva-1 lytic peptide on beneficial bacteria. Phytopathology 92: S27.

27) Fulthorpe, R.R. and R.C. Wyndham. 1991. Transfer and expression of the catabolic plasmid pBRC60 in wild bacterial recipients in a freshwater ecosystem. Appl. Environ. Microbiol. 57: 15461553.

28) Fulthorpe, R.R., C. McGowan, O.V. Maltseva, W.E. Holben and J.M. Tiedje. 1995. 4-dichlorophenoxyacetic acid-degrading bacteria contain mosaics of catabolic genes. Appl. Environ. Microbiol. 61: 3274-3281.

29) Fuqua, C. and E.P. Greenberg. 1997. Self perception in bacteria: quorum sensing with acylated monoserine lactones. Curr. Opin. Microbial. 1: 183-189.

30) Geesey, G.G., W.T. Richardson, H.G. Yeomans, R.T. Irvin and J.W. Costerton. 1977. Microscopic examination of natural sessile bacterial populations from an alpine stream. Can J. Microbiol. 23(12): 1733-1736.

31) Gray, K.M. 1997. Intercellular communication and group behavior in bacteria. Trends Microbiol. 5: 184-188.

32) Hawes, M.C., L.A. Brigham, F. Wen, H.H. Woo and Y. Zhu. 1998. Function of root border cells in plant health: pioneers in the rhizosphere. Annu. Rev. Phytopathol. 36: 311-327.

33) Hirano, S.S., E.V. Nordheim, D.C. Arny and C.D. Upper. 1982. Lognormal distribution of epiphytic bacterial populations on leaf surfaces. Appl. Environ. Microbial. 44: 695-700.

34) Hoitink, H.A.J. and M.J. Boehm. 1999. Biocontrol within the context of soil microbial communities: A substrate-dependent phenomenon. Annu. Rev. Phytopathol. 37: 427-446.

35) Hoyle, B.D. and W.J. Costerton. 1991. Bacterial resistance to antibiotics: the role of biofilms. Prog. Drug Res. 37: 91-105.

36) Kleerebezem, M., L.E. Quadri, O.P. Kruipers and W.M. de Vos. 1997. Quorum-sensing by peptide pheromones and two-component signal-transduction systems in Gram-positive bacteria. Mol. Microbiol. 24: 895-904.

37) Krause, M.S., L.V. Madden and H.A.J. Hoitink. 2001. Effect of potting mix carrying capacity on biological control of Rhizoctonia damping-off of radish and Rhizoctonia crown and root rot of poinsettia. Phytopathology 91: 1116-1123.

38) Kroer, N., T. Barkay, S. Sorensen and D. Weber. 1998. Effect of root exudates and bacterial metabolic activity on conjugal gene transfer in the rhizosphere of a marsh plant. FEMS Microbiol. Ecol. 25: 375-384.

39) Lappin, H.M., M.P. Greaves and J.H. Slater. 1985. Degradation of the herbicide mecoprop 2-2 methyl-4-chlorophenoxypropionic-acid by a synergistic microbial community. Appl. Environ. Microbiol. 49: 429-433.

40) Lawrence, J.R., D.R. Korber, G.M. Wolfaardt and D.E. Caldwell. 1995. Behavioral strategies of surface-colonizing bacteria, p. 175. In J.G. Jones (ed.), Advances in Microbial Ecology, Volume 14. Plenum Press, New York, NY.

41) Leschine, S.B. 1995. Cellulose degradation in anaerobic environments. Annu. Rev. Microbiol. 49: 399-426.

42) Loper, J.E., T.V. Suslow and M.N. Schroth. 1984. Lognormal distribution of bacterial populations in the rhizosphere. Phyto- pathology 74: 1454-1460.

43) Magnuson, R., J. Solomon and A.D. Grossman. 1994. Biochemical and genetic characterization of a competence pheromone from B. subtilis. Cell 77: 207-216.

44) Marshall, K.C. 1992. Biofilms: an overview of bacterial adhesion, activity, and control at surfaces. Am. Soc. Microbiol. News. 58: 202-207.

45) Morris, C.E., J-M. Monier and M-A. Jacques. 1997. Methods of observing microbial biofilms directly on leaf surfaces and recovering them for isolation of culturable microorganisms. Appl. Environ. Microbiol. 63: 1570-1576.

46) Morris, C.E., J-M. Monier and M-A. Jacques. 1998. A technique to quantify the population size and composition of the biofilm component in communities of bacteria in the phylloplane. Appl. Environ. Microbiol. 64: 4789-4795.

47) Nesmith, W.C. and S.F. Jenkins, Jr. 1983. Survival of Pseudomonas solanacearum in selected North Corolina soils. Phytopathology 73: 1300-1304.

48) Nesmith, W.C. and S.F. Jenkins, Jr. 1985. The influence of antagonists and controlled matric potential on survival of Pseudomonas solanacearum in four North Corolina soils. Phytopathology 75: 1182-1187.

49) Nickel, J.C., I. Ruseska, J.B. Wright and J.W. Costerton. 1985. Tobramycin resistance of Pseudomonas aeruginosa cells growing as a biofilm on urinary tract catheter. Antimicrob. Agents Chemother. 27: 619-624.

50) Normander, B., B.B. Christensen, S. Molin and N. Kroer. 1998 Effect of bacterial distribution and activity on conjugal gene transfer on the phylloplane of the bush bean (Phaseolus vulgaris). Appl. Environ. Microbiol. 64: 1902-1909.

51) O'Toole, G.A. and R. Kolter. 1998. The initiation of biofilm formation in Pseudomonas fluorescens WCS365 proceeds via multiple, convergent signaling pathways: a genetic analysis. Mol. Microbiol. 28: 449-461.

52) O'Toole, G.A., H.B. Kaplan and R. Kolter. 2000. Biofilm formation as microbial development. Annu. Rev. Microbiol. 54: 49-79.

53) Pierson, L.S. III, D.W. Wood and S.T. Chancey. 1996. Phenezine antibiotic biosynthesis in the biological control bacterium Pseudomonas aureofaciens 30-84 is regulated at multiple levels, p. 463-468. In J. Stacey, B. Mullin, and P.M. Gresshoff (ed.), Biology of Plant-Microbe Interactions. International Society for Molecular Plant-Microbe Interactions, St. Paul, MN.

54) Pirhonen, M., D. Flego, R. Heikinheimo and E.T. Palva. 1993. A small diffusible signal molecule is responsible for the global control of virulence and exoenzyme production in the plant pathogen Erwinia carotovora. EMBO J. 12: 2467-2476.

55) Robson, N.D., A.R.J. Cox, S.J. McGowan, B.W. Bycoft and G.P.C. Salmond. 1997. Bacterial N-acyl-homoserine-lactone-dependent signaling and its potential biotechnological application. Trends Biotechnol. 15: 458-464.

56) Rouse, I. and R. Baker. 1978. Modeling and quantitative analysis of biological control mechanisms of Rhizoctonia solani dampingoff of radish following soil amendment with cellulose and chitin. Phytopathology 68: 1297-1302.

57) Rovira, A.D., E.I. Newman, H.J. Bowen and R. Campbell. 1974. Quantitative assessment of the rhizosphere microflora by direct microscopy. Soil. Biol. Biochem. 6: 211-216.

58) Ruinen, J. 1961. The phyllosphere I. An ecologically neglected milieu. Plant Soil 15: 81-109.

59) Shapiro J.A. 1988. Bacteria as multicellular organisms. Sci. Am. 
256: $82-89$

60) Shapiro J.A. 1998. Thinking about bacterial populations as multicellular corganisms. Annu. Rev. Microbial. 52: 81-104.

61) Shipton, P.J., R.J. Cook and J.W. Sitton. 1973. Occurrence and transfer of a biological factor in soil that suppresses take-all of wheat in eastern Washington. Phytopathology 63: 511-517.

62) Sigee, D.C. 1993. Bacterial plant pathology: Cell and molecular aspects. Cambridge University Press, Cambridge.

63) Sissons, C.H., L. Wong and T.W. Cutress. 1995. Patterns and rates of growth of microcosm dental plaque biofilms. Oral microbial. Immunol. 10: 160-167.

64) Solomon, J.M., B.A. Lazazzera and A.D. Grossman. 1996. Purification and characterization of an extracellular peptide factor that affects two different developmental pathways in Bacillus subtilis. Genes Dev. 10: 2014-2024.
65) Tortora, G.J., B.R. Funke and C.L. Case. 2002. Microbiology: an introduction. p. 777-782, Benjamin Cummings, San Francisco.

66) Veldkamp, H. 1977. Ecological studies with the chemostat, p. 59-94. In M. Alexander (ed.), Advances in microbial ecology, Volume 1. Plenum Press, New York.

67) Veldkamp, H. and H.W. Jannasch. 1972. Mixed culture studies with the chemostat. J. Appl. Chem. Biotechnol. 22: 105-123.

68) von Bodman, S.B. and S.K. Ferrand. 1995. Capsular polysaccharide biosynthesis and pathogenicity in Erwinia stewartii require induction by an $\mathrm{N}$-acylhomoserine lactone autoinducer. J. Bacteriol. 177: 5000-5008.

69) White, J.G., W.B. Amos and M. Fordham. 1987. An evaluation of confocal versus conventional imaging of biological structure by fluorescent light microscopy. J. Cell Biol. 105: 41-48. 